\title{
Prospects of fluorescence methods application for monitoring of cyanobacterial cultures in biotechnology
} Grigoryeva N.Yu. ${ }^{l}$, Liss A.A. ${ }^{2}$

${ }^{1}$ Saint-Petersburg Scientific-Research Center for Ecological Safety RAS, Saint-Petersburg, Russia; ${ }^{2}$ Saint-Petersburg Electrotechnical University «LETI», Saint-Petersburg, Russia

E-mail: renes3@mail.ru

Key message. In the last few decades cyanbacteria became a valuable object of biotechnology. During their industrial cultivation growth rate, physiological state and algological purity of the culture should be controled permanently. One of the methods that can provide on-line monitoring of cyanobacterial cultures is a fluorescence spectroscopy.

Keywords: Cyanobacteria, fluorescence spectroscopy, industrial cultivation, on-line monitoring, physiological state Cyanobacteria are photosynthetic microorganisms that possess a high potential for innovative applications in agriculture, food production, cosmeticals, wastewater remediation, biofuels, antioxidative enzymes production, etc. In some South American and Southeast Asian countries mass cultivation of cyanobacteria already became an important part of agriculture and food industry [1]. During the industrial cultivation cyanobacterial cultures should be permanently checked to control their algological purity and the absence of additional toxic species. In this work methods of fluorescence spectroscopy, most perspective for monitoring of physiological state and biological diversity of cyanobacterial cultures during the industrial cultivation, are considered. Cyanobacterial strains from CALU collection of the Core Facility Center "Centre for Culture Collection of Microorganisms" of the Research Park of St. Petersburg State University were used in this investigation. An intrinsic self-fluorescence spectra of living cyanobacterial cultures were recorded via Cary Eclipse (Varian Cary) scanning fluorimeter and confocal laser-scanning microscope Leica TCS-SP5. It is well-known, that the intensity and spectral composition of fluorescence, emitted by cyanobacterial cells in vivo, depends on the operational effectiveness of photosynthetic apparatus, reflecting the in-time physiological state of the culture [2]. Therefore, self-fluorescence spectra, excited at the wavelengths of main photosynthetic pigments, i.e. phycoerythrin $(570 \mathrm{~nm})$, phycocyanin $(625 \mathrm{~nm})$ and chlorophyll $a(440 \mathrm{HM})$, are suggested for on-line monitoring of the developmental stage and physiological state of cyanobacterial cultures during cultivation. We suggest to monitor the algological purity of industrially cultivated cyanobacterial cultures via several characteristic fluorescence spectra, comparing them with the reference spectra of an algologically pure culture. Any changes in the fluorescence intensity of main photosynthetic pigments will indicate the presence of additional species in the industrial volume. In this work we try to emphasize methods of fluorescence spectroscopy most perspective for industrial and biotechnological applications.

\section{Перспективы применения флуоресцентных методов для мониторинга цианобактериальных культур в биотехнологии \\ Григорьева Н.Ю. ${ }^{1}$, Лисс A.A. ${ }^{2}$}

${ }^{1}$ Санкт-Петербургский Научно-исследовательский центр экологической безопасности РАН, Санкт-Петербург, Россия; ${ }^{2}$ Санкт-Петербургский государственный электротехнический университет «ЛЭТИ», Санкт-Петербург, Россия

\begin{abstract}
Аннотация. В последние несколько десятилетий циианбактерии становятся важным объектом биотехнологии. В процессе их промышленного культивирования необходимо постоянно контролировать скорость роста, физиологическое состояние и альгологическую чистота культуры. Одним из методов, который может обеспечить оперативный мониторинг культур является флуоресцентная спектроскопия.
\end{abstract}

Ключевые слова. Цианобактерии, флуоресцентная спектроскопия, промышленное культивирование, оперативный мониторинг, физиологическое состояние

Цианобактерии - это фотосинтезирующие микроорганизмы, которые обладают высоким инновационным потенциалом в сельском хозяйстве, в производстве продуктов питания, в косметике, в очистке сточных вод, производстве биотоплива и антиоксидантных ферментов и пр. В некоторых странах Южной Америки и Юго-Восточной Азии массовое выращивание цианобактерий уже стало важной частью сельского хозяйства и пищевой промышленности [1]. Во время промышленного культивирования цианобактериальные культуры необходимо постоянно мониторить на предмет контроля их альгологической чистоты и отсутствия нежелательных токсичных видов. В данной работе рассматриваются методы флуоресцентной спектроскопии, наиболее перспективные для мониторинга физиологического состояния и биологического разнообразия культур цианобактерий при промышленном культивировании. Для исследования использовались штаммы цианобактерий из коллекции САLU Ресурсного центра «Культивирования микроорганизмов» Научно-исследовательского парка СПбГУ. Спектры собственной флуоресценции живых цианобактериальных регистрировались с помощью сканирующего флуориметра Cary Eclipse (Varian Сary) и конфокального лазерного сканирующего микроскопа Leica TCS-SP5. Как известно, интенсивность и спектральный состав флуоресценции, излучаемой цианобактериальными клетками in vivo, зависит от эффективности работы фотосинтетического аппарата, отражающего, в свою очередь, физиологическое состояние культуры на данный момент [2]. Поэтому для оперативного мониторинга фазы развития и физиологического состояния культуры цианобактерий во время культивирования предлагается использовать спектры собственной флуоресценции, возбуждаемые на длинах волн основных фотосинтетических пигментов: фикоэритрина (570 нм), фикоцианина (625 нм) и хлорофилла $a$ (440 нм). Мониторинг альгологической чистоты выращиваемых цианобактериальных культур предлагается контролировать по нескольким характерным спектрам флуоресценции контролируемой культуры, сравнивая их с эталонными спектрами альгологически чистой культуры. Любые изменения интенсивности флуоресценции основных фотосинтетических пигментов укажут на наличие дополнительных видов в промышленном объеме. В данной работе мы постарались выделить методы флуоресцентной спектроскопии, наиболее перспективные для промышленного и биотехнологического применения.

[1] S.M. Reddy, S. Girisham, G.N. Babu, Applied Microbiology (agriculture, environmental, food and industrial microbiology) (Scientific Publishers, India 2017)

[2] N. Y. Grigoryeva, L. V. Chistyakova, A.A. Liss, Oceanology 58(6), 896-904 (2018). 